\title{
Induced Pluripotent Stem Cell-Derived Endothelial Cells
}

\section{Overview, Current Advances, Applications, and Future Directions}

\author{
Sae Jang, ${ }^{*}$ Alexandra Collin de l'Hortet ${ }^{\dagger}$ and Alejandro Soto-Gutierrez ${ }^{\dagger}$
}

From the Department of Internal Medicine, * Mayo Clinic, Rochester, Minnesota; and the Department of Pathology, ${ }^{\dagger}$ University of Pittsburgh, Pittsburgh, Pennsylvania

Accepted for publication

December 5, 2018.

Address correspondence to Sae Jang, M.D., Department of Internal Medicine, Mayo Clinic, 200 1st St. SW, Rochester, MN 55902; or Alexandra Collin de l'Hortet, Ph.D., Department of Pathology, University of Pittsburgh, 200 Lothrop St., 425 Biomedical Science Tower, Pittsburgh, PA 15261. E-mail: jang. sae@mayo.edu or alexandra.collin@ pitt.edu.

\begin{abstract}
Endothelial cells are prevalent in our bodies and serve multiple functions. By lining the vasculature, they provide a barrier to tissues and facilitate the transport of molecules and cells. They also maintain hemostasis and modulate blood flow by reacting to chemokines and releasing signal molecules. Thus, endothelial dysfunction leads to a wide variety of diseases, including atherosclerosis and coronary artery disease. In today's era of stem cell research, induced pluripotent stem cell-derived endothelial cells (iPSC-ECs) have emerged for research and engineering purposes. They are not only tools for studying disease states but are also a crucial part of efforts to engineer vessel and organ grafts. As the techniques in cell culture, microfluidics, and personalized medicine concomitantly improve, the potential for iPSC-ECs is enormous. We review functions of endothelium in our bodies, the development and uses of iPSC-ECs, and the possible avenues to explore in the future. (Am J Pathol 2019, 189: 502-512; https://doi.org/10.1016/j.ajpath.2018.12.004)
\end{abstract}

Endothelial cells (ECs) are epithelial cells derived from the mesoderm that line the luminal surfaces of blood and lymphatic vessels. They are dynamically involved in immune, hematological, and transport processes. In the resting state, endothelial cells regulate the transport of oxygen and micronutrients by varying vasomotor activity in reaction to molecules such as nitric oxide (NO), adrenaline, or angiotensin II. They also regulate vesicular transport and modulate barrier function by rearranging intercellular junctions and cytoskeletal proteins. Endothelial cells, which have a polygonal shape at rest, become gradually reoriented and elongated in the direction of flow on exposure to increasing shear stress. ${ }^{1}$ This reorientation streamlines the endothelial cells to decrease the effective resistance and dynamically adapt to the shear stress stimulus. Endothelial cells produce antithrombotic molecules, such as NO and prostacyclin, to prevent adhesion of leukocytes and platelets. When triggered by proinflammatory signals, such as tumor necrosis factor (TNF)- $\alpha$ or IL-6, endothelial cells up-regulate the expression of cell adhesion markers to allow immune cell migration and promote thrombosis by releasing von Willebrand factor and platelet-activating factor. Furthermore, endothelial cells interchange signal molecules with smooth muscle cells of the vasculature, platelets, and leukocytes, and they react to shear stress to minimize resistance and thrombosis. Core endothelial functions are illustrated in

\footnotetext{
Supported by NIH grant DK099257 (A.S.-G).

Disclosures: A.C.H. and A.S.-G. are inventors on a pending patent application that describes the use of human-induced pluripotent stem cells to biofabricate hepatocytes (PCT/US2018/018032). They are the cofounders of Von Baer Wolff, Inc., a company focused on production of autologous human hepatocytes from stem cell technology and reprogramming of liver failure. Their interests are managed by the Conflict of Interest Office at the University of Pittsburgh in accordance with their policies.
} 


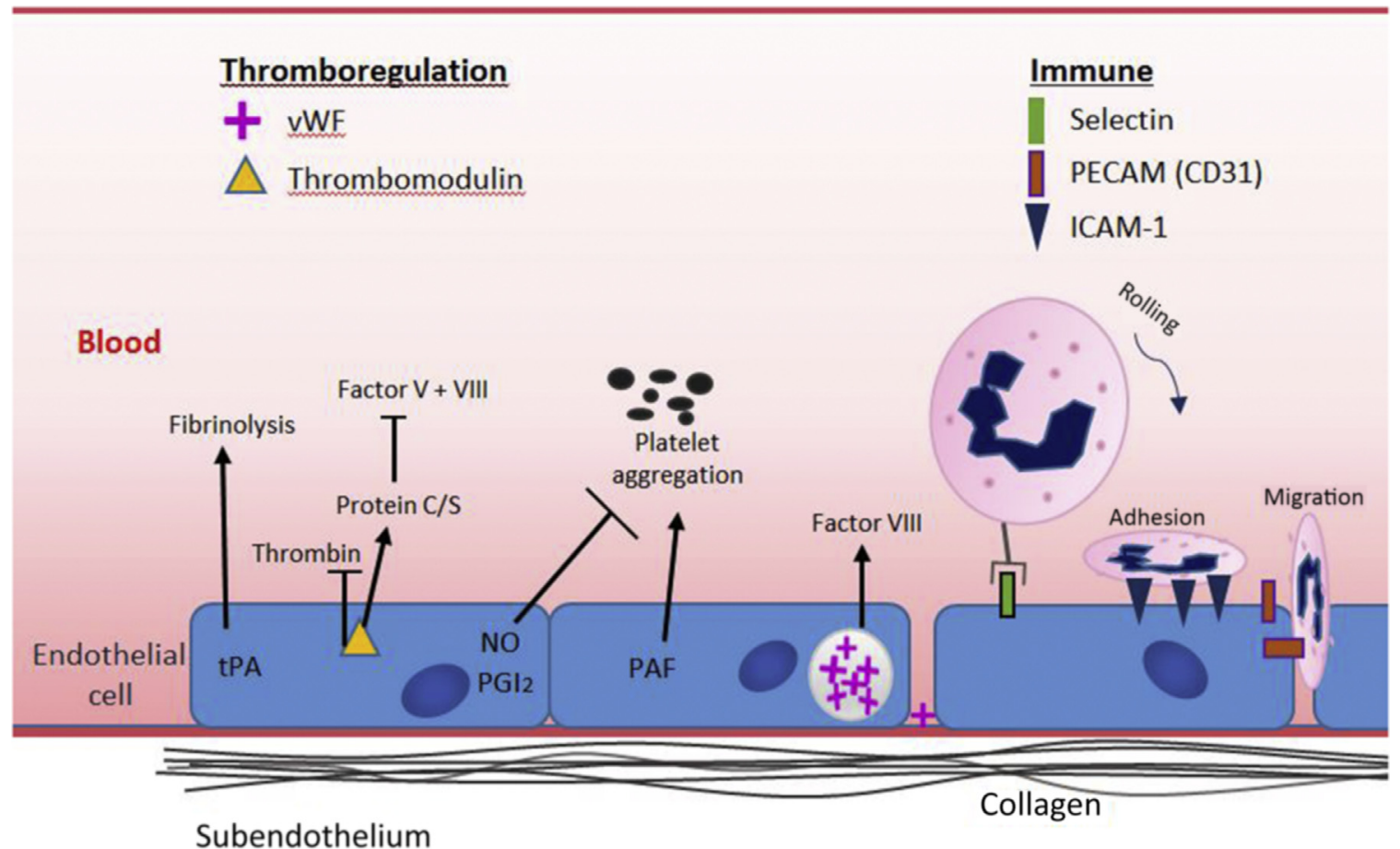

Figure 1 Schematic shows the important features of endothelial cell function. The left side of the figure highlights thromboregulation, with the left-most endothelial cell in the resting state promoting fibrinolysis and inhibiting the clotting cascade and platelet aggregation. The endothelial cell adjacent is in the active state with release of von Willebrand factor (VWF) from Weibel-Palade body and release of platelet-activating factor (PAF). VWF also initiates the clotting cascade when the subendothelium is exposed. On the right side, the immune function of endothelial cells is illustrated. A leukocyte rolls by binding to the selectin molecules expressed on the surface of endothelial cells, adheres via intercellular adhesion molecule 1 (ICAM-1; and vascular cell adhesion molecule 1, not illustrated), and migrates into the tissue. N0, nitric oxide; PECAM, platelet endothelial cell adhesion molecule 1; PGI2, prostaglandin I2; tPA, tissue plasminogen activator.

Figure 1. Further details have been discussed extensively in prior literature. $^{2-9}$

Although endothelial cells share these core functions, they also exist in great diversity. There are many ways to categorize endothelium into subtypes. For example, they can be divided by their vasculogenesis or angiogenesis formation during development-such as arterial, venous, or lymphatic; by size into macrovascular or microvascular; or in relation to organs. Morphologically, endothelial cells can be characterized as continuous, fenestrated, or sinusoidal. For example, the endothelium in the liver is sinusoidal and discontinuous to allow filtration of fluids, solutes, and macromolecules, and it can play a role in lipoprotein metabolism and atherosclerosis. ${ }^{10}$ On the other hand, macrovascular endothelium has tight junctions and maintains an impermeable barrier. Several markers have been found to be associated with these subtypes of endothelial cells. For example, these markers include Notch4, ephrin type-B receptor 4, and Coup-transcription factor II with venous subtypes; EphrinB2 and Notch1 for arterial subtypes; and podoplanin, prospero homeobox protein 1, and lymphatic vessel endothelial hyaluronan receptor 1 with lymphatic subtypes. ${ }^{11}$ Endothelium also has organ-specific functions, such as angiotensin-converting enzyme production in the lung endothelium and plasma filtration in the spleen and liver via sinusoidal endothelial cells. Because of their diversity, each subtype of endothelium has its unique array of identifiable markers. However, for research purposes, CD31 (platelet endothelial cell adhesion molecule 1), von Willebrand factor, CD144, and VEGFR2 are widely recognized as endothelial-specific markers shared across all subtypes. ${ }^{11-17}$

Given their vast presence in our body and the multiple possible pathologies in cardiovascular, hematological, and immunologic systems, endothelial cells have great potential in disease research and regenerative medicine. Currently, human endothelial cells are most commonly harvested from human umbilical veins for laboratory study. However, these cells have limited applications, because most of our vasculature consists of microvasculature. ${ }^{18}$ Autologous endothelial cells can also be harvested for therapeutic purposes, but this requires invasive protocols with surgical risks. In this review, we discuss the differentiation of endothelial cells from human-induced pluripotent stem cells (iPSCs), ongoing efforts in disease research and therapeutic applications, as well as current limitations.

\section{Induced Pluripotent Stem Cell-Derived Endothelial Cells}

iPSC technology was pioneered by Shinya Yamanaka in 2006 and holds great promise in the field of regenerative medicine. ${ }^{13}$ iPSCs are derived from easily accessible mature 
cells, such as dermal fibroblasts, and can be reprogrammed to differentiate into any of the three germ layers. There are already established methods of inducing cells into pluripotent stem cells using retrovirus techniques and ectopic expression of reprogramming factors octamer-binding transcription factor 4, sex determining region Y-box 2, Kruppel like factor 4, and c-Myc. ${ }^{13,19-22}$

\section{Development and Methods of Induction of iPSC-ECs}

iPSC-ECs have been differentiated from multiple different methods and multiple cell lines. ${ }^{11,12,14,17,20,23-26}$ The concept for development of iPSC-ECs is derived from our understanding of vascular development in embryology. Vascular endothelial cells originate from mesoderm-derived angioblasts that proliferate into endothelial cells in the presence of vascular endothelial growth factor (VEGF), mediated by miR-21 and transforming growth factor- $\beta 2 .{ }^{27}$

Methods to differentiate iPSC-ECs rely mostly on four approaches: co-culture, embryoid body formation, twodimensional culture with growth factors, and threedimensional (3D) culture (Table 1). ${ }^{11,12,14,28}$ Earlier efforts to differentiate iPSCs into endothelial cells involved coculture with stromal cells. Although the local factors from bone marrow stromal cells resulted in differentiation into endothelial cells, the yield was low, with high variability of endothelial differentiation. ${ }^{12}$ More recent efforts have been made to further characterize the differentiation pathway and increase the efficiency and yield of iPSC-ECs. Using an embryoid body formation method to differentiate iPSCs in ECs, Rufaihah et $\mathrm{al}^{11}$ showed that bone morphogenetic protein 4 plays a crucial role in differentiating iPSCs into the mesoderm lineage. In addition, high VEGF concentration was found to favor differentiation and specification into arterial subtypes, whereas VEGF-C and angiopoietin 1 were found to favor lymphatic differentiation. ${ }^{11}$

Although improved from the co-culture method, this embryoid body formation method yielded only $6 \%$ to $16 \%$ endothelial cells. ${ }^{11}$ Wang et al $^{14}$ further expanded on the differentiation method via two-dimensional Matrigel culture. In the first differentiation stage, a combination of BMP4, activin A, basic fibroblast growth factor-2, and VEGF was used to drive the differentiation of mesoderm cells into cardiovascular cells. ${ }^{14}$ Subsequently, these cells were treated with a second combination of factors-Y27632, an inhibitor of $\rho$-associated protein kinase; SB431542, an inhibitor of transforming growth factor- $\beta$ receptor; VEGF; and fibroblast growth factor-to induce the differentiation and proliferation of ECs. This direct differentiation method resulted in a decrease in production time from 2 to 3 weeks to 1 week and an increase in yield to $60 \%$.

Furthermore, differentiation of iPSCs into endothelial cells has been shown to be dependent on both the growth factors present in the culture media and the structural support of the culture. Zhang et $\mathrm{al}^{28}$ showed that endothelial cell differentiation is more efficacious when done in a $3 \mathrm{D}$ fibrin scaffold (45\% efficiency) versus in a two-dimensional culture in monolayer growth (5\% efficiency).

Endothelial cells have been differentiated into arterial, lymphatic, and venous subtypes. ${ }^{11}$ There is limited literature on iPSC differentiation into organ-specific microvascular endothelial cells, although a few studies do exist. For example, Katt et al ${ }^{29}$ developed iPSC-derived human brain microvascular endothelial cells that have been shown to express tight junction proteins, transporters, and efflux pumps. Giacomelli et $\mathrm{al}^{30}$ codifferentiated iPSC-ECs and iPSC cardiomyocytes and found that the endothelial cells expressed some cardiac markers present in primary cardiac microvasculature.

\section{iPSC-ECs versus Endogenous Endothelial Cells}

iPSC-ECs have been shown to have basic functions in immune, transport, hematological, and mechanical response. Structurally, iPSC-ECs express endothelial markers, such as CD31, CD34, and VEGFR, and are typically isolated on the basis of CD31 or CD144 (vascular endothelial-cadherin). In cultures, they can form a typical cobblestone-like shape, respond to shear stress by aligning, and form 3D networks on Matrigel in the presence of VEGF. ${ }^{11-14,28}$

Functionally, iPSC-ECs have also been shown to express hematological markers, such as angiopoietin-2, and von Willebrand factor with Weibel-Palade body-like structures seen on electron microscopy. ${ }^{17}$ They express endothelial nitric oxide synthase and have the ability to endocytose fluorescent-acetylated low-density lipoprotein. ${ }^{17,31}$

Immunologically, iPSC-ECs have responses to inflammatory markers that resemble the behavior of primary ECs, suggesting that iPSC-ECs can be used to model and study the inflammatory state. For example, when iPSCECs were exposed to proinflammatory stimuli, such as IL-1 $\beta$, TNF- $\alpha$, and lipopolysaccharide, they expressed intercellular adhesion molecule 1, vascular cell adhesion molecule 1, and E-selectin. ${ }^{11,14}$ Secretion of proinflammatory cytokines, such as monocyte chemotactic protein-1, IL-8, regulated on activation normal $\mathrm{T}$ cell expressed and secreted, and interferon- $\gamma$-induced protein 10 , was seen. ${ }^{11} \mathrm{~A}$ barrier study in iPSC-ECs showed that histamine induced a transient increase in permeability and that VEGF induced a sustained increase in permeability in a monolayer of iPSC-ECs. On the other hand, prostaglandin E2 and sphingosine-1 phosphate produced a decrease in permeability. ${ }^{17}$

Although iPSC-ECs have been shown to have basic functions in immune, transport, hematological, and mechanical response, the qualitative functionalities of iPSCECs compared with primary endothelial cells have not been fully evaluated. Current available data suggest that iPSC-ECs' functionality may not yet be as robust as that of endogenous endothelial cells. iPSC-ECs had decreased capillary sprouting and a decreased number of vessel branch points compared with human umbilical vein 
Table 1 Summary of Select iPSC-EC Differentiation Methods for Comparison

\begin{tabular}{|c|c|c|c|c|c|}
\hline $\begin{array}{l}\text { First author, year, } \\
\text { and pluripotent cell } \\
\text { type }\end{array}$ & Culture setting & $\begin{array}{l}\text { Differentiation } \\
\text { efficiency }\end{array}$ & Cell morphology & $\begin{array}{l}\text { Cell surface marker } \\
\text { and functionality }\end{array}$ & $\begin{array}{l}\text { Response to inflammatory } \\
\text { cytokines }\end{array}$ \\
\hline \multicolumn{6}{|l|}{ iPSC-ECs } \\
\hline $\begin{array}{l}\text { Choi, 2009, } \\
\text { multiple different } \\
\text { fibroblast cell } \\
\text { lines }\end{array}$ & $\begin{array}{l}\text { OP9 feeders (mouse } \\
\text { embryonic } \\
\text { fibroblast feeder } \\
\text { cell layer) }\end{array}$ & $\begin{array}{l}\text { Variable in } \\
\text { seven tested } \\
\text { human iPSC } \\
\text { lines (range, } \\
2.8 \%-6 \% \text { ) }\end{array}$ & $\begin{array}{l}\text { - Cobblestone } \\
\text { morphology on } \\
\text { culture plates } \\
\text { - Tubular structure } \\
\text { formation on } \\
\text { Matrigel }\end{array}$ & $\begin{array}{l}\text { - CD31, vWF } \\
\text { - VEGFR, VE-cadherin, } \\
\text { CD49d, CD105 }\end{array}$ & Not evaluated \\
\hline $\begin{array}{l}\text { Rufaihah, } \\
2013,{ }^{11} \\
\text { adult dermal } \\
\text { fibroblasts }\end{array}$ & $\begin{array}{l}\text { Embryoid body } \\
\text { formation method } \\
\text { Various protocols for } \\
\text { arterial, venous, } \\
\text { lymphatic, and } \\
\text { heterogeneous } \\
\text { differentiation }\end{array}$ & $6 \%-16 \%$ & $\begin{array}{l}\text { - Cobblestone } \\
\text { morphology on } \\
\text { culture plates } \\
\text { - Tubular structure } \\
\text { formation on } \\
\text { Matrigel }\end{array}$ & $\begin{array}{l}\text { - CD31, vWF } \\
\text { - VEGFR, CD144, eNOS } \\
\text { - Mixture of markers } \\
\text { associated with } \\
\text { arterial, venous, or } \\
\text { lymphatic ECs } \\
\text { - Positive Dil-ac-LDL } \\
\text { uptake }\end{array}$ & $\begin{array}{l}\text { TNF- } \alpha \text { stimulation up- } \\
\text { regulated ICAM-1 }\end{array}$ \\
\hline $\begin{array}{l}\text { Wang, 2016, } \\
\text { human adult } \\
\text { dermal } \\
\text { fibroblast }\end{array}$ & $\begin{array}{l}\text { Differentiation using } \\
\text { Matrigel culture } \\
\text { with BMP4, activin } \\
\text { A, bFGF, and VEGF }\end{array}$ & $>60 \%$ & $\begin{array}{l}\text { - Cobblestone } \\
\text { morphology on } \\
\text { culture plates } \\
\text { - Tubular structure } \\
\text { formation on } \\
\text { Matrigel }\end{array}$ & $\begin{array}{l}\text { - CD31, vWF } \\
\text { - } \text { - Alignnment in } \\
\text { longitudinal } \\
\text { differential in } \\
\text { response to low- } \\
\text { flow stress } \\
\text { modeling } \\
\text { physiological flow }\end{array}$ & $\begin{array}{l}\text { TNF- } \alpha \text { stimulation } \\
\text { increased adhesion to } \\
\text { human monocyte }+ \\
\text { disruption of tight } \\
\text { junction }\end{array}$ \\
\hline $\begin{array}{l}\text { Zhang, 2014, } \\
\text { human neonatal } \\
\text { dermal } \\
\text { fibroblasts }\end{array}$ & $\begin{array}{l}\text { Differentiated in } \\
\text { monolayer cells or } \\
\text { 3D fibrin scaffold }\end{array}$ & $\begin{array}{l}\text { Monolayer: } 5 \% \\
\text { 3D scaffold: } \\
\quad 45 \%\end{array}$ & $\begin{array}{l}\text { - Cobblestone } \\
\text { morphology on } \\
\text { culture plates } \\
\text { - Tubular structure } \\
\text { formation on } \\
\text { Matrigel }\end{array}$ & $\begin{array}{l}\text { - CD31, vWF } \\
\text { - CD144 } \\
\text { - Positive Dil-ac-LDL } \\
\text { uptake }\end{array}$ & Not evaluated \\
\hline HAECS & $\begin{array}{l}\text { Single-layer culture } \\
\text { with collagen or } \\
\text { gelatin-coated } \\
\text { plates }\end{array}$ & NA & $\begin{array}{l}\text { - Cobblestone } \\
\text { morphology with } \\
\text { large dark nuclei }\end{array}$ & $\begin{array}{l}\text { - } \text { CD31, CD105, vWF, } \\
\text { DLL1 } \\
\text { - Positive Dil-ac-LDL }\end{array}$ & $\begin{array}{l}\text { Variable among donors } \\
\text { TNF- } \alpha \text { stimulation } \\
\text { enhances expression of } \\
\text { ICAM- } 1 \text { or VCAM-1 }\end{array}$ \\
\hline $\begin{array}{l}\text { HMVECs (from all } \\
\text { sources) }\end{array}$ & $\begin{array}{l}\text { Single-layer culture } \\
\text { with collagen or } \\
\text { gelatin-coated } \\
\text { plates }\end{array}$ & NA & $\begin{array}{l}\text { - Cobblestone } \\
\text { morphology with } \\
\text { large dark nuclei } \\
\text { - Forming vessel- } \\
\text { like structures } \\
\text { with HDF in the } \\
\text { presence of VEGF }\end{array}$ & $\begin{array}{l}\text { - CD31, CD105, vWF, } \\
\text { PECAM, DLL4 } \\
\text { - Positive Dil-ac-LDL } \\
\text { - Angiogenesis }\end{array}$ & $\begin{array}{l}\text { Variable among donors } \\
\text { TNF- } \alpha \text { stimulation } \\
\text { enhances expression of } \\
\text { ICAM-1 or VCAM-1 }\end{array}$ \\
\hline
\end{tabular}

3D, three dimensional; bFGF, basic fibroblast growth factor; BMP, bone morphogenetic protein; Dil-ac-LDL, Dil-acetylated-low density lipoprotein; EC, endothelial cell; eNOS, endothelial nitric oxide synthase; HAEC, human aortic EC; HDF, human dermal fibroblasts; HMVEC, human microvascular EC; HUVEC, human umbilical vein EC; ICAM-1, intercellular adhesion molecule 1; iPSC-EC, induced pluripotent stem cell-derived EC; NA, not available; TNF- $\alpha$, tumor necrosis factor- $\alpha$; VCAM-1, vascular cell adhesion molecule 1; VE-cadherin, vascular endothelial cadherin; VEGF, vascular endothelial growth factor; VEGFR; vascular endothelial growth factor receptor 2; VWF, von Willebrand factor, Z0-1, zonula occludens protein 1. 
endothelial cells (HUVECs), ${ }^{32}$ despite another study finding that a proangiogenetic regulator, Sox17, was increased in expression in iPSC-ECs. ${ }^{33}$ In response to inflammatory signals, most iPSC-ECs expressed E-selectin and intercellular adhesion molecule 1, but only a fraction expressed vascular cell adhesion molecule $1 .{ }^{17}$ In addition, compared with HUVECs, iPSC-ECs displayed a lower VEGF-induced permeability and had a slower response to a cAMP analog. In another study, iPSC-ECs did not show a response to histamine and had a decreased response to TNF- $\alpha$ and IL- $1 \beta$ compared with primary ECs. ${ }^{33}$ Endothelial nitric oxide synthase 3 protein was lower in iPSC-ECs compared with human aortic endothelial cells. ${ }^{31}$ Given the heterogeneity of iPSC-ECs and differentiation protocols, it is difficult to generalize these findings for all iPSC-EC cell lines.

\section{Applications}

\section{Disease Modeling and Drug Screening}

With endothelial cells' wide variety of functions come many sources of dysfunction. Abnormal endothelial physiology or injury to the endothelium lining not only results in widespread systemic disease states, such as atherosclerosis and thrombosis, but also organ-specific disorders, such as preeclampsia, pulmonary hypertension, and retinopathy. In addition, endothelial cells play a critical role in a variety of human disorders, including cardiovascular disease, diabetes, chronic kidney failure, and tumor growth. ${ }^{34}$

iPSC-ECs provide the advantage of studying endothelial physiology in many variable states of differentiation and diversity in an in vitro setting under a controlled environment. iPSC-ECs can also be derived from specific disease populations to study underlying differences in gene expression or response to drugs. Several disease states are expanded on below.

\section{Atherosclerosis and Coronary Artery Disease}

Atherosclerosis is a chronic inflammatory condition and a leading cause of mortality. ${ }^{35}$ Several factors contribute to this disease, including inflammatory markers, mechanical response, lipids, and thrombosis. Tobacco smoking, abnormal circulating lipid levels, diabetes, and family medical history of cardiovascular disease are all risk factors. Endothelial dysfunction occurs before atherosclerotic lesions can be visualized, ${ }^{36}$ and identifying early markers of endothelial dysfunction and potential targets for therapy is of great interest.

There are several processes involved in endothelial dysfunction. First is an impaired release of NO and subsequent loss of vasodilation, which can lead to decreased blood perfusion of tissues. This function is closely linked to the endothelium's ability to react to mechanical shear stress. Normally, shear stress induces an atheroprotective state by orienting endothelial cells to optimize blood flow with the least resistance and by inducing $\mathrm{NO}$ and other factors to inhibit coagulation and leukocyte migration. ${ }^{6}$ However, in disease states, endothelial cells generate reactive oxygen species rather than producing NO, leading to endothelial release of chemokines and cytokines and up-regulation of adhesion molecules. ${ }^{5}$

iPSC-ECs have been shown to react to multiple factors described above; under atheroprotective flow, iPSC-ECs aligned in the direction of flow, expressed atheroprotectionassociated Kruppel-like factors 2 and 4, up-regulated endothelial nitric oxide synthase and argininosuccinate synthase 1 , and down-regulated von Willebrand factor. ${ }^{17}$ iPSC-ECs were also activated by inflammatory signals, such as TNF- $\alpha$, IL- $1 \beta$, and lipopolysaccharide; they upregulated E-selectin and intercellular adhesion molecule 1 and secreted cytokines, such as monocyte chemotactic protein-1, IL-8, and interferon- $\gamma$-induced protein 10 to mediate leukocyte migration. ${ }^{17}$

Thus far, there have been limited studies examining these endothelial functions in diseased iPSC-ECs. iPSCECs have been used to model cadmium-induced atherosclerosis to link the p38 or extracellular signal-regulated kinase signaling pathways to cadmium-induced endothelial apoptosis and dysfunction. ${ }^{37}$ Other existing studies have examined iPSC-ECs in the context of diabetes mellitus, a disease closely linked to endothelial dysfunction with devastating long-term end-organ damage. In diabetes, hyperinsulinemia leads to endothelin-1 secretion and increased expression of vascular cell adhesion molecule 1 and E-selectin, which promotes vasoconstriction and an inflammatory state. ${ }^{38}$ Hyperglycemia increases reactive oxygen species, leading to decreased NO secretion. ${ }^{39}$ In a mouse model study, iPSC-ECs derived from diet-induced obese mice demonstrated a reduced capacity to proliferate, migrate, and form cord-like structures in vitro. ${ }^{40}$ When used in a hind limb ischemic experiment-in which endothelial cells are injected into mice with ischemic limbs to examine changes in perfusion-iPSC-ECs from obese mice were inferior to iPSC-ECs from normal mice, with increased muscle atrophy and presence of inflammatory cells. $^{40}$

In an analogous mouse study for coronary artery disease, human arterial or venous iPSC-ECs were injected into mice with a ligated left coronary artery. The survival rate of mice injected with arterial endothelial cells was comparable to those injected with venous endothelial cells. These iPSCECs were found to have greater NO production rate, greater protective response to shear stress, and lower TNF$\alpha$-induced inflammatory response than HUVECs. ${ }^{41}$ Another study administering human iPSC-ECs into immunodeficient mice showed that iPSC-ECs promoted angiogenesis of ischemic hind limb region and improved perfusion by $30 \%$ by comparison to vehicle group. ${ }^{42}$ These proof-of-concept studies are encouraging for pursuing iPSCEC-derived clinical applications in ischemic diseases, such as peripheral artery disease and coronary artery disease. 


\section{Response to Pharmacologic Agents}

In the age of personalized medicine and pharmacogenomics, iPSC-ECs provide the ability to study the autologous endothelium's response to drugs. Thus far, iPSC-ECs have been studied in lipid transport in the context of HMG-CoA reductase inhibitors. Simvastatin up-regulated kruppel-like factor 2, nitric oxide synthase 3, argininosuccinate synthase 1 , thrombomodulin, integrin subunit beta 4 , and prostaglandin D2 synthase and down-regulated proinflammatory angiopoietin 2 and endothelin 1 in iPSC-ECs at similar concentrations as primary ECs. ${ }^{17}$ In a study of iPSC-ECs derived from obese and normal mice, the iPSC-ECs responded to pravastatin with cell migration, proliferation, inhibition of apoptosis, and an increase in NO levels. ${ }^{40}$ These appropriate pharmaceutical responses suggest that iPSC-ECs are candidates for studying lipid transport in both normal and disease states.

iPSC-ECs have not yet been used in studying other classes of drugs and their pharmacogenetics. Other iPSCderived cells, such as cardiomyocytes and vascular smooth muscle cells, have been used to study the pharmacogenetics of antihypertensive drugs and may be of use in patients with resistant hypertension. ${ }^{43}$ As the field of pharmacogenomics progresses, iPSC-derived cells may become more relevant in identifying clinically significant and targetable mutations.

\section{Organ-on-a-Chip}

An organ-on-a-chip is a 3D microfluidic cell-culture chip with the aim of converging research in tissue engineering, semiconductor fabrication, and human cell sourcing to generate reproducible and minimalistic organ tissue pathophysiology. The need for this technology has emerged from the current limitations of animal models and the promise of an unlimited supply of high-quality, patient-specific, iPSC-derived cells. Establishing a functional organ unit model could bridge discrepancies between traditional two-dimensional cell cultures and animal model studies with failed clinical trials. ${ }^{44,45}$ The $\mathrm{NIH}$-including the National Center for Advancing Translational Sciences-is funding a complete program dedicated to developing human tissue chips, with the objective to better predict drug safety and efficacy. In this context, some groups have focused their efforts on building a human vascular microphysiological system for in vitro drug screening using human cord-blood-derived endothelial progenitor cells ${ }^{46}$ or even iPSC-ECs. ${ }^{47}$ Their results highlight the potential of microphysiological systems to improve the study of human diseases, drug responses, and 3D vascular network engineering.

\section{Graft Engineering}

\section{Valvular Grafts}

Generating durable and nonimmunogenic valvular grafts is of great interest in cardiac valvulopathies. Currently, homografts, xenografts, and mechanical prosthetic devices are used as short-term solutions for correcting heart defects. ${ }^{48}$
However, patients receiving these grafts often require repeated surgeries to replace prostheses that degenerate over time. In cases of young patients, these grafts also lack the ability to grow with the recipients' bodies and hearts.

Although studies that examine valvular grafts composed of iPSC-ECs still need to be conducted, findings point toward iPSC-ECs being a promising resource for multiple reasons. First, endothelial cells have been shown to improve outcomes in these engineered grafts. Cases of porcine heart valve implantation without reendothelialization have ended in mortality due to valvular rupture or severe degeneration, likely caused by a severe inflammatory response triggered by exposed xenogenic collagen matrices. ${ }^{49}$

Second, autologously sourced cells have better structural integrity because of reduced immunogenicity and inflammation. Valvular grafts generated from autologous and allogenic endothelial sources were compared in sheep models; there was trivial pulmonary regurgitation in autografts, whereas there was moderate regurgitation in allogenic valves, demonstrating the superiority of autografts to allografts in structural integrity. ${ }^{50}$

Last, grafts generated with stem cells or progenitor cells may have the ability to adapt and grow with the recipient patient. A pulmonary valve seeded with autologous endothelial progenitor cells increased in size proportionately with the child and resulted in the resolution of the valvulopathy, suggesting that the tissue-engineered valve had the potential to remodel and grow when seeded with circulating mononuclear hematopoietic progenitor cells. ${ }^{51}$

\section{Vascular Grafts}

Vascular grafts are applicable predominantly in cardiovascular disease, but also in other areas, such as interventional nephrology for high-flow arteriovenous fistulas required in dialysis for end-stage kidney disease patients. ${ }^{52-56}$ There is a shortage of autologous blood vessels because of the fact that patients who require grafts already have existing systemic endothelial dysfunction and vascular disease. Furthermore, most vascular grafts in the lower extremities fail in the first decade due to progressive endothelial dysfunction and intimal narrowing. ${ }^{57}$ There are commercial polymeric bypass grafts available; however, patency outcomes are poor for small-diameter grafts. ${ }^{58}$ For these reasons, engineering autologous vessel grafts designed to be less prone to atherosclerosis is of great interest.

Efforts have been directed at seeding polymeric vascular grafts with endothelial and smooth muscle cells to generate a functional replacement that is structurally resilient to aneurysm formation and resistant to thrombosis and inflammation. One study used both iPSC-ECs and iPSCderived smooth muscle cells seeded onto nanofibular scaffolds to generate vascular grafts. ${ }^{57}$ The designed nanofibrils of the scaffolds directed the preferential alignment of the endothelial cells in the direction of flow to decrease inflammatory response and monocyte adhesion. The endothelial-seeded graft had significantly reduced monocyte 
adhesion. When compared with primary endothelial cells, iPSC-ECs aligned in a similar manner.

Other engineering approaches have focused on threedimensional printing technology. The advantages of such technology include an accurate control of the tissue tridimensional architecture and composition, high precision, and reproducibility through automation. There are no articles exploring the use of iPSC-ECs for bioprinting vascular grafts, but it has been proved to be a promising approach using primary human endothelial cells. In rodent models of hind-limb ischemia and myocardial infection, it was demonstrated that implantation of 3D-printed grafts rescued the perfusion of distal tissues and prevented capillary loss, muscle atrophy, and loss of function. ${ }^{59}$

\section{Supportive Role in Organogenesis}

By driving vascularization, iPSC-ECs hold the potential to support organogenesis and improve the functionality of the generated tissue. This has been proved with iPSC-derived liver buds cultured with HUVECS. Within 48 hours of transplantation into immune-deficient mice, these liver buds became vascularized tissues, exhibiting liver-specific maturation features, such as protein production and human-specific drug metabolism. ${ }^{60,61} \mathrm{~A}$ recent article published by Camp et $\mathrm{al}^{62}$ dissected the effect of interlineage communication between endothelial cells and hepatoblasts during liver bud development. The authors used single-cell RNA sequencing to decipher hepatocyte lineage progression during organogenesis and found that hepatic cell maturation was improved in the presence of HUVECS. In addition, using a receptor-ligand pairing analysis and a highthroughput inhibitor assay, they showed that the VEGF pathway potentiates hepatoblast differentiation and is essential to liver bud development. Similarly, recellularization of an intestine graft with human iPSC-derived intestinal epithelium and HUVECS resulted in the maturation of the intestinal epithelium and the development of nutrient $a b$ sorption functionality after transplantation into rats. ${ }^{63}$

The supportive role of endothelial cells in organogenesis using iPSC-ECs has also been demonstrated. In an organon-chip of the spinal cord, iPSC-derived brain microvascular cells promoted the maturation of iPSC-derived neuronal cells into spinal cord neural tissue.$^{64}$ Recently, a study showed the generation of iPSC-derived cardiac microtissues via simultaneous differentiation of cardiomyocytes and endothelial cells to recapitulate the cardiomyocyte-endothelium cross talk present in native human physiology. This in vitro model resulted in beating 3D cardiac microtissues and an increased expression of genes associated with cardiomyocyte maturation. ${ }^{30}$ Similarly, 3D myocardial tissue constructed with human iPSCderived cardiomyocytes, vascular mural cells, and ECs demonstrated excellent in vitro structural maturation and electromechanical performance. Implantation of this engineered cardiac tissue into in vivo rat models of myocardial infarction resulted in regenerated and revascularized myocardium with improvement in the left ventricular function. ${ }^{65}$ Foster et al ${ }^{66}$ also showed that culturing corneal organoids derived from iPSCs led to the development of a self-organized, multilayered architecture that shared characteristics of epithelial, stromal, and endothelial cells. This study highlights that maturation of iPSC-derived organoids also relies on the formation of self-assembled endothelial cells. The potential role of iPSC-ECs to support maturation and functionality in organogenesis remains to be fully explored, but it promises to be an attractive avenue of investigation for regenerative medicine.

\section{Grafts for Whole-Organ Transplantation}

The field of transplant medicine has rapidly grown. Organ transplant is the preferred therapy for eligible patients with end-stage organ failure, but it comes with surgical and medical complication risks, such as organ rejection, and a lifetime course of immunosuppression with increased risk of toxicity, infection, and cancer. In addition, there is a national organ graft shortage with wait lists that are growing over time as more institutions implement transplant services. ${ }^{67}$ In recent years, there have been efforts to engineer organ grafts that are less immunogenic with an adequate functional capacity for transplantation.

One approach to organ engineering is to recellularize extracellular matrices obtained by decellularizing unusable organs. iPSC-ECs are highly relevant to this method of whole-organ graft engineering for two major reasons. First, the iPSC-derivation technology presents the possibility of building an entire organ derived from patients' cells to reduce the risks of rejection and immunosuppression. Second, endothelialized vascular supply is critical in proper transport, hemostasis, immune processes, organ maturation, and organ functionality. Endothelial cells not only protect parenchymal cells from the shear stress of the blood flow, but they also provide barrier protection from the exposed subendothelium of the vasculature. Without reendothelialization, the exposed extracellular matrices are thrombogenic, leading to thrombosis and distal necrosis of the transplanted organ. Bioengineered organs without endothelialized vasculature cannot maintain flow for greater than a few hours because of blood clotting. ${ }^{68}$ When organ matrices are decellularized, they maintain their vascular structure as well as the basement membrane and elastin fibers. ${ }^{69}$ The initial step of preparing the scaffold to maintain structural integrity can be crucial in supporting revascularization; scaffolds that were prepared with $4 \%$ sodium deoxycholate had a greater area of endothelial cell coverage compared with those prepared with $8 \mathrm{mmol} / \mathrm{L} \quad 3-[(3-$ cholamidopropyl)dimethylammonio]-1-propanesulfonate (CHAPS) and 1\% SDS. ${ }^{70}$ Furthermore, the scaffold may play an important role in the further differentiation of endothelial cells. When embryonic stem cells were seeded into a kidney scaffold, they proliferated into glomerular, vascular, and tubular structures with expression of differentiated immunohistochemical markers. ${ }^{71}$ In addition, the seeded embryonic stem cells also 
remodeled the laminin and collagen of their basement membranes. ${ }^{72}$ In disease studies, the extracellular matrix has been shown to remodel in atheroprone regions with increased fibronectin, suggesting that the endothelium dynamically interacts with its surrounding matrix. ${ }^{29}$

Reendothelialization has been explored in a variety of organs. In prior literature, human embryonic stem cells were cultured and then transplanted into severe combined immunodeficiency mice, where they formed capillaries along mouse vasculature. ${ }^{25}$ Rat hearts were recellularized with rat aortic endothelial cells via media perfusion; the endothelial cells implanted onto endocardial surfaces, ventricular cavities, and the vascular tree, and they formed single layers in both larger and smaller coronary vessels. ${ }^{73}$ Reendothelialization of the rat heart reduced scaffold thrombogenicity and improved left ventricular contractility and vascular tree. ${ }^{74} \mathrm{In}$ the lung, organ scaffolds have been repopulated with human umbilical cord endothelial cells, which successfully implanted throughout the scaffold vasculature. ${ }^{75}$ Kidney scaffolds have also been revascularized with human umbilical cord endothelial cells, with successful repopulation of the vasculature. ${ }^{76}$ Vascular resistance was found to be decreased after reendothelialization, although it was still higher than in cadaveric kidneys.

No published work, to our knowledge, has yet described iPSC-ECs repopulating organ scaffolds.

\section{Summary, Limitations, and Future Directions}

iPSC-ECs are highly relevant in both disease studies and therapeutic interventions. Multiple protocols have been established for differentiating iPSCs into endothelial cells, with ongoing efforts to further delineate more efficient methods of increasing yield, decreasing time, and further specializing differentiation into arterial, venous, or lymphatic types. Techniques in microfluidics may present opportunities to better control shear stress and cytokine concentration to increase the yield and specificity of cellular products.

There are several limitations of iPSC-ECs. Methods have not been established yet to differentiate iPSC-ECs into various organ-specific subtypes. Such progress would allow researchers to manipulate and study the functionality of organ-specific diseases, such as diabetic retinopathy, coronary artery disease, and pulmonary arterial hypertension. One approach currently proposed for studying pulmonary arterial hypertension is to compare the gene expression changes in iPSC-ECs versus primary ECs obtained from sites of interest to assess methylation changes. ${ }^{77}$ Understanding disease states and genetic alterations in iPSC-ECs could help develop primary prevention treatments targeting endothelial dysfunction.

Furthermore, iPSC-ECs have yet to be thoroughly tested in vivo for vascular and valvular grafts. Although stem cells and progenitor cells have been shown to be able to adapt to patients' developmental growth, iPSC-ECs have not been studied in this context. Moreover, iPSC-ECs will still need to be tested for several safety measures, including their propensity to form teratomas in vivo before being used for clinical applications. Therefore, safe, efficient, functional, and scalable protocols to differentiate iPSC-ECs will need to be thoroughly tested before reaching a clinical trial.

In addition, iPSC-derived grafts may not be practical in real-life practice; to generate autologously derived iPSCderived grafts, foresight is required to construct grafts in time for surgical repair. As such, the use of iPSC-ECs may be less suited for cardiac surgery cases or for congenital heart defects in newborns, and may be more appropriate for nonemergent elective surgeries or in cases in which congenital heart disease is diagnosed in utero by ultrasound. ${ }^{78}$ To circumvent this limitation, one option would be to use differentiated and ready-to-go iPSC-ECs for allogeneic transplantations. To this end, several organizations, such as the Global Alliance for iPSC Therapies, are working on a human leukocyte antigen haplobank to provide a repository of information on GMP and clinical-grade iPSC cell lines covering the worldwide population. ${ }^{79-81}$ Other groups are working on generating potential universal iPSC donor cells with minimal allogeneic response by engineering edited iPSC cells that express minimally polymorphic human leukocyte antigen-E molecules. ${ }^{82,83}$

Future work could include engineering iPSC-ECs to generate vessel grafts with a decreased inflammatory response to reduce risk of atherosclerosis and intimal hyperplasia at the site of surgery due to intraoperative injury and subsequent monocyte adhesion. ${ }^{84}$ In the field of organogenesis, the next steps are to characterize the reendothelialization of scaffolds and to study interactions between the extracellular matrix, surrounding cells, and iPSC-ECs.

\section{References}

1. Malek AM, Izumo S: Mechanism of endothelial cell shape change and cytoskeletal remodeling in response to fluid shear stress. J Cell Sci 1996, 109:713-726

2. Brunner H, Cockcroft JR, Deanfield J, Donald A, Ferrannini E, Halcox J, Kiowski W, Luscher TF, Mancia G, Natali A, Oliver JJ, Pessina AC, Rizzoni D, Rossi GP, Salvetti A, Spieker LE, Taddei S, Webb DJ; Working Group on Endothelins and Endothelial Factors of the European Society of Hypertension: Endothelial function and dysfunction, part II: association with cardiovascular risk factors and diseases: a statement by the Working Group on Endothelins and Endothelial Factors of the European Society of Hypertension. J Hypertens 2005, 23:233-246

3. Cines DB, Pollak ES, Buck CA, Loscalzo J, Zimmerman GA, McEver RP, Pober JS, Wick TM, Konkle BA, Schwartz BS, Barnathan ES, McCrae KR, Hug BA, Schmidt AM, Stern DM: Endothelial cells in physiology and in the pathophysiology of vascular disorders. Blood 1998, 91:3527-3561

4. Deanfield J, Donald A, Ferri C, Giannattasio C, Halcox J, Halligan S, Lerman A, Mancia G, Oliver JJ, Pessina AC, Rizzoni D, Rossi GP, Salvetti A, Schiffrin EL, Taddei S, Webb DJ; Working Group on Endothelin and Endothelial Factors of the European Society of Hypertension: Endothelial function and dysfunction, part I: 
methodological issues for assessment in the different vascular beds: a statement by the Working Group on Endothelin and Endothelial Factors of the European Society of Hypertension. J Hypertens 2005, 23:7-17

5. Deanfield JE, Halcox JP, Rabelink TJ: Endothelial function and dysfunction: testing and clinical relevance. Circulation 2007, 115: 1285-1295

6. Michiels C: Endothelial cell functions. J Cell Physiol 2003, 196 : 430-443

7. Pober JS, Sessa WC: Evolving functions of endothelial cells in inflammation. Nat Rev Immunol 2007, 7:803-815

8. Fair DS, Marlar RA, Levin EG: Human endothelial cells synthesize protein S. Blood 1986, 67:1168-1171

9. Chan V, Chan TK: Antithrombin III in fresh and cultured human endothelial cells: a natural anticoagulant from the vascular endothelium. Thromb Res 1979, 15:209-213

10. Braet F, Wisse E: Structural and functional aspects of liver sinusoidal endothelial cell fenestrae: a review. Comp Hepatol 2002, 1:1

11. Rufaihah AJ, Huang NF, Kim J, Herold J, Volz KS, Park TS, Lee JC, Zambidis ET, Reijo-Pera R, Cooke JP: Human induced pluripotent stem cell-derived endothelial cells exhibit functional heterogeneity. Am J Transl Res 2013, 5:21-35

12. Choi KD, Yu J, Smuga-Otto K, Salvagiotto G, Rehrauer W, Vodyanik M, Thomson J, Slukvin I: Hematopoietic and endothelial differentiation of human induced pluripotent stem cells. Stem Cells 2009, 27:559-567

13. Takahashi K, Tanabe K, Ohnuki M, Narita M, Ichisaka T, Tomoda K, Yamanaka S: Induction of pluripotent stem cells from adult human fibroblasts by defined factors. Cell 2007, 131:861-872

14. Wang L, Xiang M, Liu Y, Sun N, Lu M, Shi Y, Wang X, Meng D, Chen S, Qin J: Human induced pluripotent stem cells derived endothelial cells mimicking vascular inflammatory response under flow. Biomicrofluidics 2016, 10:014106

15. Lui KO, Zangi L, Silva EA, Bu L, Sahara M, Li RA, Mooney DJ, Chien KR: Driving vascular endothelial cell fate of human multipotent Isl1+ heart progenitors with VEGF modified mRNA. Cell Res 2013, 23:1172-1186

16. Middleton J, Americh L, Gayon R, Julien D, Mansat M, Mansat P, Anract P, Cantagrel A, Cattan P, Reimund JM, Aguilar L, Amalric F, Girard JP: A comparative study of endothelial cell markers expressed in chronically inflamed human tissues: MECA-79, Duffy antigen receptor for chemokines, von Willebrand factor, CD31, CD34, CD105 and CD146. J Pathol 2005, 206:260-268

17. Adams WJ, Zhang Y, Cloutier J, Kuchimanchi P, Newton G, Sehrawat S, Aird WC, Mayadas TN, Luscinskas FW, GarciaCardena G: Functional vascular endothelium derived from human induced pluripotent stem cells. Stem Cell Reports 2013, 1:105-113

18. Hewett PW: Isolation and culture of human endothelial cells from micro- and macro-vessels. Methods Mol Biol 2016, 1430:61-76

19. Takahashi K, Yamanaka S: Induction of pluripotent stem cells from mouse embryonic and adult fibroblast cultures by defined factors. Cell 2006, 126:663-676

20. White MP, Rufaihah AJ, Liu L, Ghebremariam YT, Ivey KN, Cooke JP, Srivastava D: Limited gene expression variation in human embryonic stem cell and induced pluripotent stem cell-derived endothelial cells. Stem Cells 2013, 31:92-103

21. Yu J, Vodyanik MA, Smuga-Otto K, Antosiewicz-Bourget J, Frane JL, Tian S, Nie J, Jonsdottir GA, Ruotti V, Stewart R, Slukvin II, Thomson JA: Induced pluripotent stem cell lines derived from human somatic cells. Science 2007, 318:1917-1920

22. Papapetrou EP, Tomishima MJ, Chambers SM, Mica Y, Reed E, Menon J, Tabar V, Mo Q, Studer L, Sadelain M: Stoichiometric and temporal requirements of Oct4, Sox2, Klf4, and c-Myc expression for efficient human iPSC induction and differentiation. Proc Natl Acad Sci U S A 2009, 106:12759-12764

23. Orlova VV, Drabsch Y, Freund C, Petrus-Reurer S, van den Hil FE, Muenthaisong S, Dijke PT, Mummery CL: Functionality of endothelial cells and pericytes from human pluripotent stem cells demonstrated in cultured vascular plexus and zebrafish xenografts. Arterioscler Thromb Vasc Biol 2014, 34:177-186

24. Taura D, Sone M, Homma K, Oyamada N, Takahashi K, Tamura N, Yamanaka S, Nakao K: Induction and isolation of vascular cells from human induced pluripotent stem cells: brief report. Arterioscler Thromb Vasc Biol 2009, 29:1100-1103

25. Levenberg S, Golub JS, Amit M, Itskovitz-Eldor J, Langer R: Endothelial cells derived from human embryonic stem cells. Proc Natl Acad Sci U S A 2002, 99:4391-4396

26. Orlova VV, van den Hil FE, Petrus-Reurer S, Drabsch Y, Ten Dijke P, Mummery CL: Generation, expansion and functional analysis of endothelial cells and pericytes derived from human pluripotent stem cells. Nat Protoc 2014, 9:1514-1531

27. Di Bernardini E, Campagnolo P, Margariti A, Zampetaki A, Karamariti E, Hu Y, Xu Q: Endothelial lineage differentiation from induced pluripotent stem cells is regulated by microRNA-21 and transforming growth factor beta2 (TGF-beta2) pathways. J Biol Chem 2014, 289:3383-3393

28. Zhang S, Dutton JR, Su L, Zhang J, Ye L: The influence of a spatiotemporal 3D environment on endothelial cell differentiation of human induced pluripotent stem cells. Biomaterials 2014, 35: 3786-3793

29. Katt ME, Linville RM, Mayo LN, Xu ZS, Searson PC: Functional brain-specific microvessels from iPSC-derived human brain microvascular endothelial cells: the role of matrix composition on monolayer formation. Fluids Barriers CNS 2018, 15:7

30. Giacomelli E, Bellin M, Sala L, van Meer BJ, Tertoolen LG, Orlova VV, Mummery CL: Three-dimensional cardiac microtissues composed of cardiomyocytes and endothelial cells co-differentiated from human pluripotent stem cells. Development 2017, 144: $1008-1017$

31. Collado MS, Cole BK, Figler RA, Lawson M, Manka D, Simmers MB, Hoang S, Serrano F, Blackman BR, Sinha S, Wamhoff BR: Exposure of induced pluripotent stem cell-derived vascular endothelial and smooth muscle cells in coculture to hemodynamics induces primary vascular cell-like phenotypes. Stem Cells Transl Med 2017, 6:1673-1683

32. Bezenah JR, Kong YP, Putnam AJ: Evaluating the potential of endothelial cells derived from human induced pluripotent stem cells to form microvascular networks in 3D cultures. Sci Rep 2018, 8:2671

33. Halaidych OV, Freund C, van den Hil F, Salvatori DCF, Riminucci M, Mummery CL, Orlova VV: Inflammatory responses and barrier function of endothelial cells derived from human induced pluripotent stem cells. Stem Cell Reports 2018, 10:1642-1656

34. Rajendran $P$, Rengarajan $T$, Thangavel J, Nishigaki $Y$, Sakthisekaran D, Sethi G, Nishigaki I: The vascular endothelium and human diseases. Int J Biol Sci 2013, 9:1057-1069

35. Barquera S, Pedroza-Tobias A, Medina C, Hernandez-Barrera L, Bibbins-Domingo K, Lozano R, Moran AE: Global overview of the epidemiology of atherosclerotic cardiovascular disease. Arch Med Res 2015, 46:328-338

36. Hadi HA, Carr CS, Al Suwaidi J: Endothelial dysfunction: cardiovascular risk factors, therapy, and outcome. Vasc Health Risk Manag 2005, 1:183-198

37. Tang L, Su J, Liang P: Modeling cadmium-induced endothelial toxicity using human pluripotent stem cell-derived endothelial cells. Sci Rep 2017, 7:14811

38. Muniyappa R, Sowers JR: Role of insulin resistance in endothelial dysfunction. Rev Endocr Metab Disord 2013, 14:5-12

39. Carcamo-Orive I, Huang NF, Quertermous T, Knowles JW: Induced pluripotent stem cell-derived endothelial cells in insulin resistance and metabolic syndrome. Arterioscler Thromb Vasc Biol 2017, 37: 2038-2042

40. Gu M, Mordwinkin NM, Kooreman NG, Lee J, Wu H, Hu S, Churko JM, Diecke S, Burridge PW, He C, Barron FE, Ong SG, Gold JD, Wu JC: Pravastatin reverses obesity-induced dysfunction of 
induced pluripotent stem cell-derived endothelial cells via a nitric oxide-dependent mechanism. Eur Heart J 2015, 36:806-816

41. Zhang J, Chu LF, Hou Z, Schwartz MP, Hacker T, Vickerman V, Swanson S, Leng N, Nguyen BK, Elwell A, Bolin J, Brown ME, Stewart R, Burlingham WJ, Murphy WL, Thomson JA: Functional characterization of human pluripotent stem cell-derived arterial endothelial cells. Proc Natl Acad Sci U S A 2017, 114:E6072-E6078

42. Rufaihah AJ, Huang NF, Jame S, Lee JC, Nguyen HN, Byers B, De A, Okogbaa J, Rollins M, Reijo-Pera R, Gambhir SS, Cooke JP: Endothelial cells derived from human iPSCS increase capillary density and improve perfusion in a mouse model of peripheral arterial disease. Arterioscler Thromb Vasc Biol 2011, 31:e72-e79

43. Biel NM, Santostefano KE, DiVita BB, El Rouby N, Carrasquilla SD, Simmons C, Nakanishi M, Cooper-DeHoff RM, Johnson JA, Terada N: Vascular smooth muscle cells from hypertensive patientderived induced pluripotent stem cells to advance hypertension pharmacogenomics. Stem Cells Trans1 Med 2015, 4:1380-1390

44. Ronaldson-Bouchard K, Vunjak-Novakovic G: Organs-on-a-chip: a fast track for engineered human tissues in drug development. Cell Stem Cell 2018, 22:310-324

45. Huh D, Matthews BD, Mammoto A, Montoya-Zavala M, Hsin HY, Ingber DE: Reconstituting organ-level lung functions on a chip. Science 2010, 328:1662-1668

46. Fernandez CE, Yen RW, Perez SM, Bedell HW, Povsic TJ, Reichert WM, Truskey GA: Human vascular microphysiological system for in vitro drug screening. Sci Rep 2016, 6:21579

47. Kurokawa YK, Yin RT, Shang MR, Shirure VS, Moya ML, George SC: Human induced pluripotent stem cell-derived endothelial cells for three-dimensional microphysiological systems. Tissue Eng Part C Methods 2017, 23:474-484

48. Mirensky TL, Breuer CK: The development of tissue-engineered grafts for reconstructive cardiothoracic surgical applications. Pediatr Res 2008, 63:559-568

49. Simon P, Kasimir MT, Seebacher G, Weigel G, Ullrich R, SalzerMuhar U, Rieder E, Wolner E: Early failure of the tissue engineered porcine heart valve SYNERGRAFT in pediatric patients. Eur J Cardiothorac Surg 2003, 23:1002-1006. discussion 1006

50. Cho SW, Park HJ, Ryu JH, Kim SH, Kim YH, Choi CY, Lee MJ, Kim JS, Jang IS, Kim DI, Kim BS: Vascular patches tissueengineered with autologous bone marrow-derived cells and decellularized tissue matrices. Biomaterials 2005, 26:1915-1924

51. Cebotari S, Lichtenberg A, Tudorache I, Hilfiker A, Mertsching H, Leyh R, Breymann T, Kallenbach K, Maniuc L, Batrinac A, Repin O, Maliga O, Ciubotaru A, Haverich A: Clinical application of tissue engineered human heart valves using autologous progenitor cells. Circulation 2006, 114:I132-I137

52. Gui L, Niklason LE: Vascular tissue engineering: building perfusable vasculature for implantation. Curr Opin Chem Eng 2014, 3:68-74

53. Cleary MA, Geiger E, Grady C, Best C, Naito Y, Breuer C: Vascular tissue engineering: the next generation. Trends Mol Med 2012, 18: 394-404

54. Kurobe H, Maxfield MW, Breuer CK, Shinoka T: Concise review: tissue-engineered vascular grafts for cardiac surgery: past, present, and future. Stem Cells Transl Med 2012, 1:566-571

55. Naito Y, Shinoka T, Duncan D, Hibino N, Solomon D, Cleary M, Rathore A, Fein C, Church S, Breuer C: Vascular tissue engineering: towards the next generation vascular grafts. Adv Drug Deliv Rev 2011, 63:312-323

56. Efstratiadis G, Platsas I, Koukoudis P, Vergoulas G: Interventional nephrology: a new subspecialty of nephrology. Hippokratia 2007, 11 : $22-24$

57. Nakayama KH, Joshi PA, Lai ES, Gujar P, Joubert LM, Chen B, Huang NF: Bilayered vascular graft derived from human induced pluripotent stem cells with biomimetic structure and function. Regen Med 2015, 10:745-755

58. Veith FJ, Gupta SK, Ascer E, White-Flores S, Samson RH, Scher LA, Towne JB, Bernhard VM, Bonier P, Flinn WR, Astelford P, Yao J,
Bergan JJ: Six-year prospective multicenter randomized comparison of autologous saphenous vein and expanded polytetrafluoroethylene grafts in infrainguinal arterial reconstructions. J Cell Sci 1986, 3: 104-114

59. Mirabella T, MacArthur JW, Cheng D, Ozaki CK, Woo YJ, Yang M, Chen CS: 3D-printed vascular networks direct therapeutic angiogenesis in ischaemia. Nat Biomed Eng 2017, 1. pii:0083

60. Takebe T, Sekine K, Enomura M, Koike H, Kimura M, Ogaeri T, Zhang RR, Ueno Y, Zheng YW, Koike N, Aoyama S, Adachi Y, Taniguchi H: Vascularized and functional human liver from an iPSC-derived organ bud transplant. Nature 2013, 499: 481-484

61. Takebe T, Zhang RR, Koike H, Kimura M, Yoshizawa E, Enomura M, Koike N, Sekine K, Taniguchi H: Generation of a vascularized and functional human liver from an iPSC-derived organ bud transplant. Nat Protoc 2014, 9:396-409

62. Camp JG, Sekine K, Gerber T, Loeffler-Wirth H, Binder H, Gac M, Kanton S, Kageyama J, Damm G, Seehofer D, Belicova L, Bickle M, Barsacchi R, Okuda R, Yoshizawa E, Kimura M, Ayabe H, Taniguchi H, Takebe T, Treutlein B: Multilineage communication regulates human liver bud development from pluripotency. Nature 2017, 546:533-538

63. Kitano K, Schwartz DM, Zhou H, Gilpin SE: Bioengineering of functional human induced pluripotent stem cell-derived intestinal grafts. Nat Commun 2017, 8:765

64. Sances S, Ho R, Vatine G, West D, Laperle A, Meyer A, Godoy M, Kay PS, Mandefro B, Hatata S, Hinojosa C, Wen N, Sareen D, Hamilton GA, Svendsen CN: Human iPSC-derived endothelial cells and microengineered organ-chip enhance neuronal development. Stem Cell Reports 2018, 10:1222-1236

65. Masumoto H, Nakane T, Tinney JP, Yuan F, Ye F, Kowalski WJ, Minakata K, Sakata R, Yamashita JK, Keller BB: The myocardial regenerative potential of three-dimensional engineered cardiac tissues composed of multiple human iPS cell-derived cardiovascular cell lineages. Sci Rep 2016, 6:29933

66. Foster JW, Wahlin K, Adams SM, Birk DE, Zack DJ, Chakravarti S: Cornea organoids from human induced pluripotent stem cells. Sci Rep 2017, 7:41286

67. Abouna GM: Organ shortage crisis: problems and possible solutions. Transplant Proc 2008, 40:34-38

68. Caralt M, Velasco E, Lanas A, Baptista PM: Liver bioengineering: from the stage of liver decellularized matrix to the multiple cellular actors and bioreactor special effects. Organogenesis 2014, 10: $250-259$

69. Soto-Gutierrez A, Zhang L, Medberry C, Fukumitsu K, Faulk D, Jiang H, Reing J, Gramignoli R, Komori J, Ross M, Nagaya M, Lagasse E, Stolz D, Strom SC, Fox IJ, Badylak SF: A whole-organ regenerative medicine approach for liver replacement. Tissue Eng Part C Methods 2011, 17:677-686

70. Faulk DM, Carruthers CA, Warner HJ, Kramer CR, Reing JE, Zhang L, D'Amore A, Badylak SF: The effect of detergents on the basement membrane complex of a biologic scaffold material. Acta Biomater 2014, 10:183-193

71. Ross EA, Williams MJ, Hamazaki T, Terada N, Clapp WL, Adin C, Ellison GW, Jorgensen M, Batich CD: Embryonic stem cells proliferate and differentiate when seeded into kidney scaffolds. J Am Soc Nephrol 2009, 20:2338-2347

72. Ross EA, Abrahamson DR, St John P, Clapp WL, Williams MJ, Terada N, Hamazaki T, Ellison GW, Batich CD: Mouse stem cells seeded into decellularized rat kidney scaffolds endothelialize and remodel basement membranes. Organogenesis 2012, 8:49-55

73. Ott HC, Matthiesen TS, Goh SK, Black LD, Kren SM, Netoff TI, Taylor DA: Perfusion-decellularized matrix: using nature's platform to engineer a bioartificial heart. Nat Med 2008, 14:213-221

74. Robertson MJ, Dries-Devlin JL, Kren SM, Burchfield JS, Taylor DA: Optimizing recellularization of whole decellularized heart extracellular matrix. PLoS One 2014, 9:e90406 
75. Ott HC, Clippinger B, Conrad C, Schuetz C, Pomerantseva I, Ikonomou L, Kotton D, Vacanti JP: Regeneration and orthotopic transplantation of a bioartificial lung. Nat Med 2010, 16:927-933

76. Song JJ, Guyette JP, Gilpin SE, Gonzalez G, Vacanti JP, Ott HC: Regeneration and experimental orthotopic transplantation of a bioengineered kidney. Nat Med 2013, 19:646-651

77. Rabinovitch M: Combining induced pluripotent stem cell with next generation sequencing technology to gain new insights into pathobiology and treatment of pulmonary arterial hypertension. Pulm Circ 2013, 3:153-155

78. Schmidt D, Mol A, Neuenschwander S, Breymann C, Gossi M, Zund G, Turina M, Hoerstrup SP: Living patches engineered from human umbilical cord derived fibroblasts and endothelial progenitor cells. Eur J Cardiothorac Surg 2005, 27:795-800

79. Turner M, Leslie S, Martin NG, Peschanski M, Rao M, Taylor CJ, Trounson A, Turner D, Yamanaka S, Wilmut I: Toward the development of a global induced pluripotent stem cell library. Cell Stem Cell 2013, 13:382-384

80. Wilmut I, Leslie S, Martin NG, Peschanski M, Rao M, Trounson A, Turner D, Turner ML, Yamanaka S, Taylor CJ: Development of a global network of induced pluripotent stem cell haplobanks. Regen Med 2015, 10:235-238

81. Lee S, Huh JY, Turner DM, Lee S, Robinson J, Stein JE, Shim SH, Hong CP, Kang MS, Nakagawa M, Kaneko S, Nakanishi M, Rao MS, Kurtz A, Stacey GN, Marsh SGE, Turner ML, Song J: Repurposing the cord blood bank for haplobanking of HLAhomozygous iPSCs and their usefulness to multiple populations. Stem Cells 2018, 00:1-15

82. Gornalusse GG, Hirata RK, Funk SE, Riolobos L, Lopes VS, Manske G, Prunkard D, Colunga AG, Hanafi LA, Clegg DO, Turtle C, Russell DW: HLA-E-expressing pluripotent stem cells escape allogeneic responses and lysis by NK cells. Nat Biotechnol 2017, 35:765-772

83. Riolobos L, Hirata RK, Turtle CJ, Wang PR, Gornalusse GG, Zavajlevski M, Riddell SR, Russell DW: HLA engineering of human pluripotent stem cells. Mol Ther 2013, 21:1232-1241

84. Eslami MH, Gangadharan SP, Belkin M, Donaldson MC, Whittemore AD, Conte MS: Monocyte adhesion to human vein grafts: a marker for occult intraoperative injury? J Vasc Surg 2001, 34:923-929 